\title{
Applied Principles for Ensuring Economic Security of Economic Systems in the Conditions of Digitalization
}

\author{
SVITLANA TULCHYNSKA \\ Department of Economics and Entrepreneurship \\ National Technical University of Ukraine "Igor Sikorsky Kyiv Polytechnic Institute" \\ Kyiv, UKRAINE \\ OLEKSANDR SOLOSICH \\ Department of Economics and Entrepreneurship \\ National Technical University of Ukraine "Igor Sikorsky Kyiv Polytechnic Institute" \\ Kyiv, UKRAINE \\ MAKSYM MARYCH \\ Department of Finance and Credit \\ Yuriy Fedkovych Chernivtsi National University \\ Chernivtsi, UKRAINE \\ NATALIIA MARUSIAK \\ Department of Finance and Credit \\ Yuriy Fedkovych Chernivtsi National University \\ Chernivtsi, UKRAINE \\ OKSANA LASHUK \\ Department of Public Administration and Organizational Management \\ Chernihiv Polytechnic National University \\ Chernihiv, UKRAINE
}

\begin{abstract}
Within the article, a methodical approach to assessing economic security of regional economic systems in the context of digitalization, which is built using a systems approach, is proposed. The sequence of stages of the economic security assessment of regional economic systems in the conditions of digitalization is offered. To assess security of economic systems, it is justified to use the method of the hierarchical cluster analysis, which involves initial consideration of each of the objects as a separate cluster and then to combine them according to the similarity criterion until two final clusters are formed. The approbation of the offered methodical approach to the analysis of economic safety of economic systems in the conditions of active processes of digitization on an example of the regions of Ukraine is carried out.
\end{abstract}

Key-Words: - Economic security, Economic system, Region, Digitalization, System approach.

Received: April 15, 2021. Revised: October 23, 2021. Accepted: November 3, 2021. Published: November 30, 2021.

\section{Introduction}

Modern processes of economic development are marked by the intensification of paradigmatic transformations in the structure of progressive economies of the world towards the post-industrial vector of socio-economic development, which occur in parallel with active processes of regionalization and globalization, which on the one hand erode spatial and political barriers, and on the other hand, they actualize problems of the development of regional economic systems as integral economic and legal complexes - points of perspective economic growth [19-22]. However, the development of these processes cannot be a reason to ignore the growing set of contradictions, which are embodied in a number of crisis phenomena of a destructive nature, the sources of which serve as objective (climate change, historical disparities in socio-economic development, pandemic consequences, etc.), and 
subjective factors (conflict of national economic interests, artificially inspired and deliberately catalyzed problems of social, economic, political, cultural development, etc.) [26-30]. Thus, the priority issues are to ensure economic security of regional systems in order to solve the outlined problems and to achieve optimal parameters of intra-system development of regional education.

The purpose of this study is to develop methodological tools for determining the level of economic security of economic systems in the context of digitalization. To achieve this goal, the authors solved the following tasks: substantiated the use of the method of the hierarchical cluster analysis to assess the economic security system; the sequence of stages of carrying out of the economic safety estimation of regional economic systems in the conditions of digitalization is offered; the approbation of the offered methodical approach to the analysis of economic safety of regional economic systems in the conditions of active processes of digitization on an example of the regions of Ukraine is carried out.

\section{Literature Review}

Many scientific researches of modern foreign and domestic scientists are devoted to the study of economic security, sustainable development of regions and modern processes of digitalization, among which: Abramova A. (2021) [1], Agarkov G.A. (2019) [2]; Akhmetshin E.M. (2018) [3]; Burlutskiy S. (2019) [4], Dobrovolska O. (2021) [5], Dubyna M. (2021) [6]; Glechikova N. (2020) [7]; Grigoraş-Ichim C.E. (2018) [8]; Kholiavko N. (2020) [9], Kholod S. (2021) [10], Kozyrieva O. (2020) [11]; Kudryavtseva T. (2021) [12]; Mayorova T. (2020) [13]; Mejokh Z. (2019) [14]; Mints A. (2019) [15], Pesotskiy A.A. (2020) [16]; Pestryakov A. (2020) [17]; Pinchuk A. (2019) [18], Popelo O. (2021) [19]; Lagodiienko N. (2021) [20]; Marhasova V. (2021) [21]; Revko A., Butko M. (2020) [22]; Rudenko M.N. (2019, 2020) [23-24]; Shkarlet S. (2020) [25]; Ivanova N. (2020) [26]; Nusinova O. (2021) [27]; Trusova N.V. (2020) [28]; Garafonova O. (2021) [29]; Zhygalkevych Zh. (2021) [30]; Vovk O. (2021) [31]; Viknianska A. (2021) [32]; Viknianska A. (2021) [33], Kravchenko M. (2021) [34] and others.

The authors of article [17] argue that digitalization determines the development of all processes in social and economic spheres, including the issue of strengthening economic security. The work [16] is aimed at systematizing threats to economic security of the country in terms of the nature of relations between economic entities and public authorities in the context of globalization. The author's approach to the characterization of risks caused by both excessive and insufficient administrative influence on the activities of transnational and other large companies is presented.

The purpose of article [34] is to develop a method for assessing threats to economic security of the region. The importance of the method is that by grouping the regions on the basis of the proposed method it is possible to develop individual tools for monitoring economic security. The authors of the article [2] note that ensuring economic security is a priority for the development of both the regional socio-economic system, and the economy as a whole. Support for safe development of economy is due to two components that form the generalized structure of the economic security concept, namely: providing conditions for economic growth and improving the quality of life in the region.

The aim of the study [28] is a comprehensive assessment of the innovative development of agribusiness in Ukraine within the economic security framework. The guiding method of research has become a modified systems approach. The purpose of article [24] is to develop recommendations for improving the economic security level of Perm region. The authors considered the essence of the economic security mechanism of the region, identified its components and main directions of this mechanism functioning, analyzed indicators of economic security, pointed out problems of economic security and solution development. Work [7] focuses on the current state of economic security of the regions. In the course of research, a model of the economic security system was built on the basis of index assessment.

Within the paper [14] the main problems and areas of improving the transport and logistics infrastructure of the city in order to increase economic security of the region and increasing its socio-economic development are discussed. The purpose of the study is to assess the level of the development of the transport and logistics system of the city as an element of economic security of the region to determine the ways to form new transport routes that provide comfortable movement of citizens in right directions.

Scholars [23] argue that the problem of economic security of its territorial units is extremely important for the creation of a state as independent unit in the world, special relevance of which in terms of transformational change and globalization is in scientific, theoretical, economic and political 
aspects. The purpose of the article [3] is to develop solutions to improve economic development of the region in order to stabilize its economic security. Within the work, the dialectical-materialist method of cognition and general scientific, special and private-scientific methods based on it are used.

\section{Methodology}

To assess security of regional economic systems in terms of digitization, the authors propose the use of one of the most effective methodological tools for classifying objects, namely the cluster analysis, which involves the analysis of a large array of source data, which is a set of relevant quantitative values. parameters and their subsequent association on the basis of the maximum similarity criterion for the formation of homogeneous groups of objects clusters.

The choice of the cluster analysis in the process of studying economic security of regional economic systems in terms of digitization, due to a number of advantages that allow to ensure the use of this technique, in particular:

- combination of qualitative and quantitative aspects of identification of stable groups of objects (the first is achieved through the individual selective approach in the choice of analyzed parameters, and the second - the mathematical apparatus of the analysis);

- possibility of using large arrays of input data, heterogeneous in type, nature and dimension of the analyzed parameters in their composition;

- presence of a wide range of methods of the cluster analysis, the choice of which is made in accordance with the purpose of the study;

- clarity of the obtained results of mathematical calculations.

In this study, the authors proposed the use of the method of hierarchical cluster analysis, which involves initial consideration of each of the objects as a separate cluster and then their combination according to the similarity criterion until two final clusters are formed, with the advantage of the method of hierarchical cluster analysis over the method of k-means is the possibility of forming a mathematically justified number of cluster formations (rather than pre-subjectively given) and low sensitivity of this tool to the so-called emissions in the analysis of observations. The procedure of carrying out the hierarchical cluster analysis of the economic safety maintenance of regional economic systems in the conditions of digitalization is generalized, it is possible to present the sequence presented in Fig. 1.

Stages of assessing economic security of regional economic systems in the context of digitalization

\begin{tabular}{|l|} 
The first stage: identification of indicators-criteria of clustering \\
The second stage: substantiation of the method of the square of the Euclidean distance of calculation of distances \\
between points of the plane formed by an array of initial indicators of clustering criteria \\
The third stage: substantiation of use of Ward's method of calculation of distances between clusters at calculation of \\
the economic safety maintenance of regional economic systems in the conditions of digitalization \\
The fourth stage: interpretation of the results of the cluster analysis of economic security of regional economic \\
systems in the context of digitalization
\end{tabular}

Fig. 1: The sequence of stages of assessing economic security of regional economic systems in terms of digitalization

Source: built by the authors.

The first stage. Identification of indicatorscriteria of clustering, within which the authors proposed the use of 30 indicators of economic security of regional entities in the context of digitalization, as well as their structuring according to the functional orientation of certain parameters in 
Table 1. Characteristics of indicators-criteria of economic security of regional formations in the conditions of digitalization

\begin{tabular}{|c|c|c|}
\hline $\begin{array}{l}\text { Name of the } \\
\text { functional block of } \\
\text { indicators-criteria }\end{array}$ & $\begin{array}{l}\text { Composition of the functional block of indicators- } \\
\text { criteria }\end{array}$ & $\begin{array}{l}\text { Characteristics of the functional } \\
\text { block of indicators-criteria }\end{array}$ \\
\hline $\begin{array}{l}\text { Indicators of stable } \\
\text { operation }\end{array}$ & $\begin{array}{l}\text { Gross regional product per capita, number of } \\
\text { economically active enterprises, unemployment rate, } \\
\text { amount of arrears of wages, capital investment, } \\
\text { volume of sold industrial products, disposable income } \\
\text { per capita, average wages by region per month, net } \\
\text { profit (loss) of enterprises, number of detected crimes }\end{array}$ & $\begin{array}{l}\text { This functional block of indicators } \\
\text { characterizes capabilities of the } \\
\text { regional economic system to maintain a } \\
\text { sustainable level of the basic } \\
\text { development indicators, which form the } \\
\text { resource and organizational and } \\
\text { economic basis for ensuring more } \\
\text { effective forms of its safe operation. }\end{array}$ \\
\hline $\begin{array}{l}\text { Indicators of } \\
\text { effective functioning }\end{array}$ & $\begin{array}{l}\text { Industrial production indices, level of population } \\
\text { participated in labor force, natural population growth, } \\
\text { profitability of operating activities of enterprises by } \\
\text { types of economic activity, share of exports in total } \\
\text { foreign trade in goods, growth / decrease of pollutants } \\
\text { and greenhouse gases from stationary sources of } \\
\text { emissions per capita, consumer price index, capital } \\
\text { investment index, construction products index, waste } \\
\text { generation (hazard class IV) per unit area }\end{array}$ & $\begin{array}{l}\text { This functional block covers criteria } \\
\text { that reflect capabilities of the regional } \\
\text { system for effective reproduction and } \\
\text { the overall potential for adaptation and } \\
\text { improvement of the existing economic } \\
\text { processes in accordance with the } \\
\text { intellectualized vector of the security } \\
\text { development of regional economic } \\
\text { systems }\end{array}$ \\
\hline $\begin{array}{l}\text { Indicators of } \\
\text { progressive } \\
\text { functioning }\end{array}$ & $\begin{array}{l}\text { Number of innovatively active industrial enterprises, } \\
\text { volumes of financing of internal expenses for research } \\
\text { and development, number of employees involved in } \\
\text { research and development, volume of expenses for } \\
\text { innovations of industrial enterprises, number of higher } \\
\text { education institutions, number of industrial enterprises } \\
\text { implementing innovations (products and / or } \\
\text { technological processes), number of registered } \\
\text { collective agreements, number of subscribers } \\
\text { connected to the Internet, number of applications for } \\
\text { inventions, cost of environmental protection }\end{array}$ & $\begin{array}{l}\text { This functional block of criteria } \\
\text { characterizes the presence of the basic } \\
\text { elements of the innovation, knowledge } \\
\text { and information infrastructure of the } \\
\text { regional system in the context of } \\
\text { digitalization, while reflecting available } \\
\text { opportunities to ensure economic } \\
\text { security of the regional development in } \\
\text { the face of threats and challenges of the } \\
\text { economic space digitalization. }\end{array}$ \\
\hline
\end{tabular}

Source: formed by the authors.

On the basis of the formed list of indicatorscriteria of carrying out of clustering of the economic safety maintenance of regional economic systems in the conditions of digitalization, the search of corresponding indicators and the formation of an array of initial data for the implementation of further mathematical calculations is carried out.

The second stage. The choice of the method of calculating distances between the points of the plane formed by the array of initial indicators of the clustering criteria. According to the authors, in the process of the regions' clustering in terms of economic security of regional economic systems in terms of digitization, it is appropriate to use the method of the square of the Euclidean distance according to the following formula (1):

$$
d\left(z_{i}, z_{j}\right)=\sum_{k=1}^{m}\left(z_{i j}-z_{i k}\right)^{2}
$$

where $z_{i j}$ - standardized value of the $\mathrm{j}$-th object on the $i$-th indicator-criterion;

$z_{i k}-$ standardized value of the $\mathrm{k}$-th object on the $j$-th indicator-criterion.

We will add that prior the application of this method of the distances calculation between points of the plane standardization of values of the formed array of initial data of indicators-criteria of carrying out clustering of the economic safety maintenance of regional economic systems in the conditions of digitization is carried out according to the formula (2):

$$
z_{i j}=\frac{x_{i j}-\bar{x}_{j}}{\sigma_{x j}}
$$

where $x_{i j}$ - value of the i-th indicator-criterion for the $\mathrm{j}$-th array; 
$\bar{x}_{j}-$ average value of the i-th indicator-criterion for the $\mathrm{j}$-th array;

$\sigma_{x j}-$ standard deviation of the i-th indicatorcriterion.

The third stage. The choice of the clustering method, which consists in the specifics of calculating the distances between clusters when calculating economic security of regional economic systems in terms of digitization, which is represented by a wide range of scientific methods. In this study, the authors proposed the use of the Ward's method, which is motivated by the correspondence of theoretical ideas about the cluster concept within this methodological tool and the author's understanding of this concept, which forms the methodological unity of the chosen approach.

According to the Ward's method, it is necessary to calculate the following indicators: error of the sum of squares of observations - ESS (formula (3)); total sum of squares - TSS (formula (4)); share of variation of observations is $\mathrm{r}^{2}$ (formula (5)). Calculation formulas of the presented indicators are given below.

$$
E S S=\sum_{i} \sum_{j} \sum_{k}\left|x_{i j k}-\bar{x}_{i k}\right|^{2}
$$

where $x_{i j k}$-value of the $k$-th indicator-criterion in the $j$-th observation, which belongs to the $i$-th cluster.

In the process of this indicator calculating, the values of the indicators-criteria for each object of the cluster are compared with the average value of this indicator for the cluster, the differences are summed.

$$
T S S=\sum_{i} \sum_{j} \sum_{k}\left|x_{i j k}-\bar{x}_{\ldots k}\right|^{2}
$$

The calculation of this indicator allows you to compare individual objects in the cluster according to the corresponding indicators-criteria, comparing their values, specific to an individual object and the average for the indicator.

$$
r^{2}=\frac{T S S-E S S}{T S S}
$$

The indicator of the fate of variation allows you to analyze the homogeneity degree of the formed set of objects of the cluster analysis.

The Ward's method is implemented by performing successive iterations to calculate the corresponding indicators, with each of the iterations combining objects of the cluster analysis in such a way as to minimize the level of error of the sum of squares (ESS) and to maximize the value of the variation fraction $\left(\mathrm{r}^{2}\right)$.

The fourth stage. Interpretation of the results of the cluster analysis to ensure economic security of regional economic systems in the context of digitalization. Within this stage, it is proposed to use a universal method of presenting the results of the cluster analysis, namely by using a tree-type diagram - dendrogram. Dendrogram is a multi-level diagram formed as a result of a sequential process of combining objects into clusters, while demonstrating the distance of cluster formations from each other.

\section{Results}

Approbation of the above methodological approach to the economic security analysis of regional economic systems in the context of active digitization processes was carried out on the example of the regions of Ukraine using the specialized software, namely IBM SPSS Statistics (hierarchical cluster analysis) and MS Excel. Based on the data of macroeconomic statistics, the grouping of indicators of economic security of regions in the context of digitalization was carried out in accordance with the list of indicators-criteria presented in Table 2.

As a result of the cluster analysis of ensuring economic security of the regions in terms of digitization, the following dendrogram was obtained (Fig. 2). 


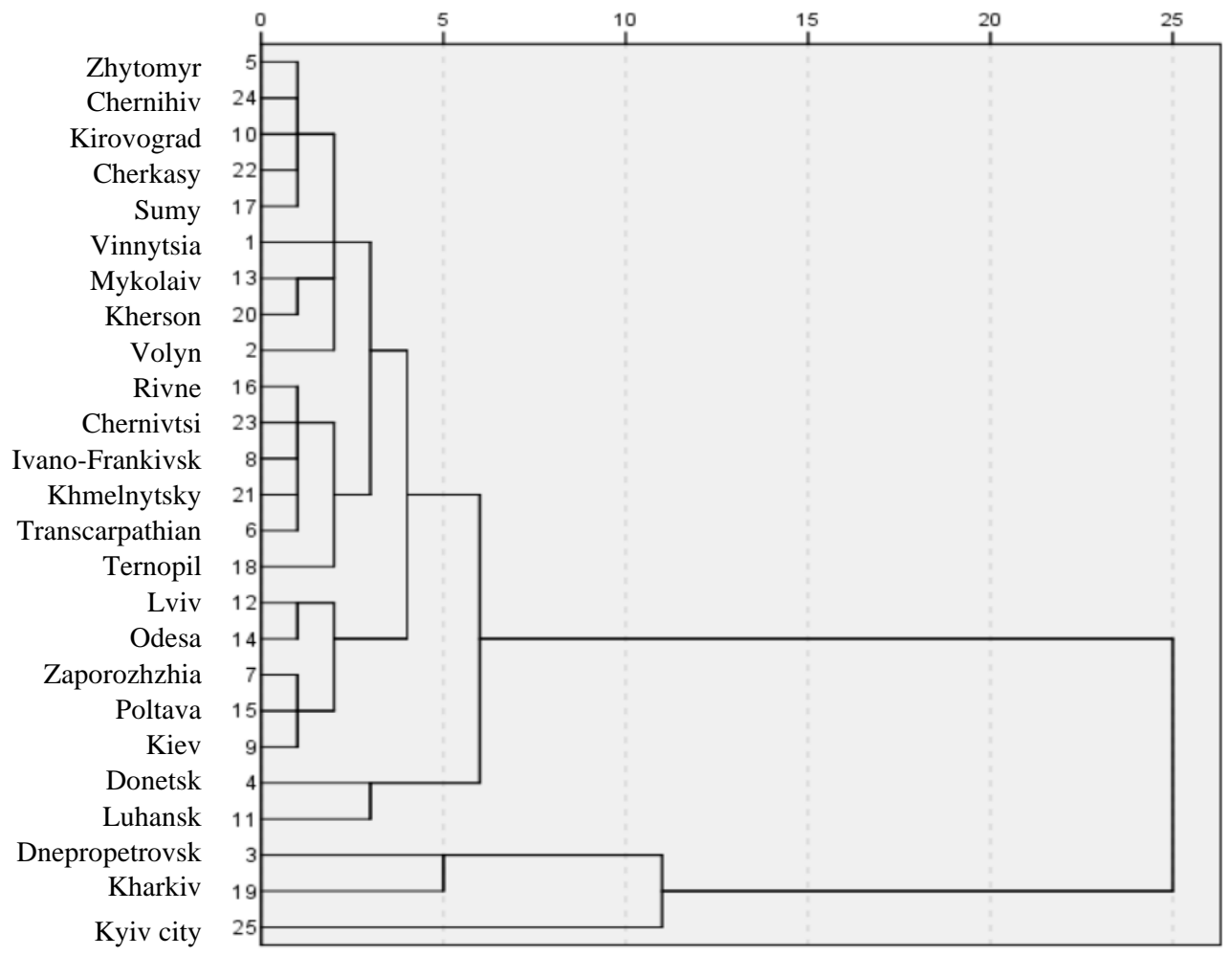

Fig. 2: Dendrogram of the regions clustering in Ukraine in accordance with the level of economic security in terms of digitalization in 2020 Source: built by the authors.

Thus, according to the results of the regions clustering in Ukraine in accordance with the level of economic security in terms of digitalization in 2020 , we can distinguish five clusters. The first cluster is represented by 1 region, the second cluster includes 2 regions, the third cluster unites 5 regions, the fourth -15 , the fifth -2 (Fig. 3).

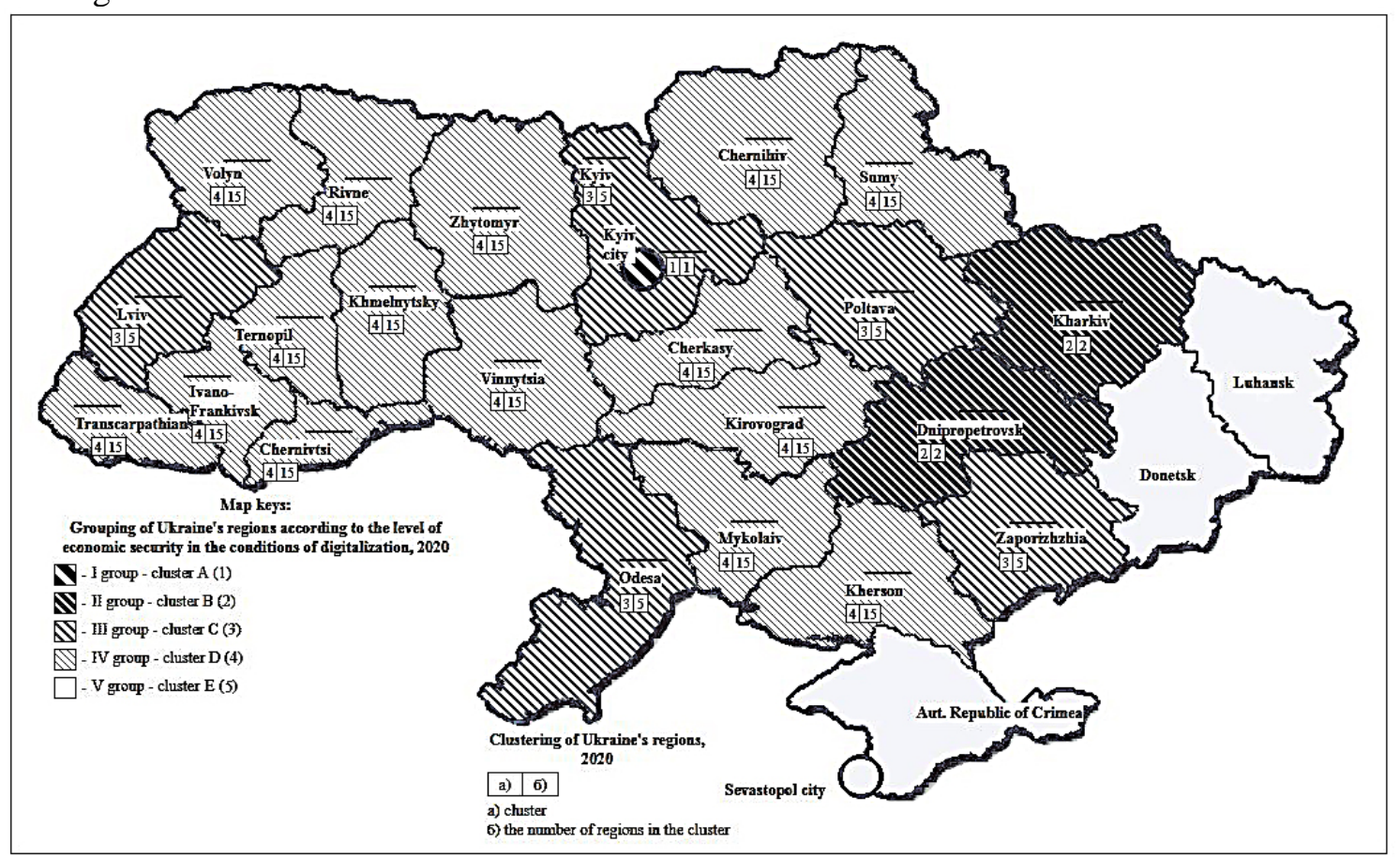

Fig. 3: Grouping of the regions of Ukraine according to the results of clustering according to the level of economic security in terms of digitalization, 2020

Source: built by the authors. 
A detailed description and a brief description of these clusters are given in Table 2.

Table 2. Characteristics of cluster formations in accordance with the level of economic security in terms of digitalization in 2020

\begin{tabular}{|c|c|c|}
\hline $\begin{array}{c}\text { Cluster } \\
\text { name }\end{array}$ & Cluster composition & Characteristic \\
\hline A & Kyiv city & $\begin{array}{l}\text { The most developed region in terms of security indicators; this cluster is } \\
\text { characterized by a high level of industrial development, the availability of the } \\
\text { appropriate infrastructure for the development of innovation processes, high } \\
\text { indicators of socio-economic development; the cluster is one of the centers of } \\
\text { the concentration of key political, business, knowledge and public institutions } \\
\text { and organizations }\end{array}$ \\
\hline B & $\begin{array}{c}\text { Dnipropetrovsk, Kharkiv } \\
\text { regions }\end{array}$ & $\begin{array}{l}\text { This cluster is represented by two powerful industrial regions of Ukraine, } \\
\text { which are complex diversified industrial complexes, including mechanical } \\
\text { engineering, machine tool, chemical-pharmaceutical and food industries. The } \\
\text { cluster includes a large number of innovation infrastructure facilities, higher } \\
\text { education institutions and has a high level of training; the most threatening } \\
\text { indicators are ecological environment of the regions of this cluster }\end{array}$ \\
\hline $\mathrm{C}$ & $\begin{array}{l}\text { Lviv, Odessa, Zaporizhia, } \\
\text { Poltava, Kiev regions }\end{array}$ & $\begin{array}{l}\text { The cluster combines a number of industrialized regions, in particular in the } \\
\text { fields of mechanical engineering, light and pulp and paper industries, metal } \\
\text { processing, as well as ferrous and nonferrous metallurgy (Zaporizhia region). } \\
\text { The regions included in the cluster have high human development rates and } \\
\text { have a sufficient level of financial and infrastructural support for the } \\
\text { implementation of innovative development processes. }\end{array}$ \\
\hline $\mathrm{D}$ & $\begin{array}{l}\text { Zhytomyr, Chernihiv, } \\
\text { Kirovohrad, Cherkasy, Sumy, } \\
\text { Vinnytsia, Mykolaiv, } \\
\text { Kherson, Volyn, Rivne, } \\
\text { Chernivtsi, Ivano-Frankivsk, } \\
\text { Khmelnytsky, Zakarpattia, } \\
\text { Ternopil regions }\end{array}$ & $\begin{array}{l}\text { From the point of view of the quantitative composition of the regions, the } \\
\text { cluster, which includes regions with medium and low level of industrial } \\
\text { development, as well as relevant indicators of human development, which } \\
\text { significantly reduces the overall innovation potential of the cluster in the } \\
\text { context of digitalization }\end{array}$ \\
\hline $\mathrm{E}$ & Luhansk, Donetsk regions & $\begin{array}{l}\text { The cluster includes two regions, which in the past were the central elements } \\
\text { of domestic industrial potential, but due to active hostilities, economic } \\
\text { prospects for the cluster development remain uncertain, and opportunities for } \\
\text { the intensification of investment and innovation processes - minimal }\end{array}$ \\
\hline
\end{tabular}

Source: formed by the authors.

Thus, the cluster analysis of the regions of Ukraine in accordance with the level of economic security in the context of digitalization allowed to identify five main cluster formations, united on the basis of the similarity of security indicators and trends in their change.
In the Table, the dynamics of changes in the composition of clusters on the level of economic security in terms of digitalization during 2016-2020 on the basis of calculations on a similar indicatorcriterion composition in previous years are presented.

Table 3. Dynamic indicators of the state of clustering of the regions of Ukraine by the level of economic security in terms of digitalization during 2016-2020

\begin{tabular}{|l|c|c|c|c|c|}
\hline \multirow{2}{*}{ Region } & \multicolumn{5}{|c|}{ Years } \\
\cline { 2 - 6 } & 2016 & 2017 & 2018 & 2019 & 2020 \\
\hline Vinnytsia & $\mathrm{D}$ & $\mathrm{D}$ & $\mathrm{D}$ & $\mathrm{D}$ & $\mathrm{D}$ \\
\hline Volyn & $\mathrm{D}$ & $\mathrm{D}$ & $\mathrm{D}$ & $\mathrm{D}$ & $\mathrm{D}$ \\
\hline Dnepropetrovsk & $\mathrm{B}$ & $\mathrm{B}$ & $\mathrm{B}$ & $\mathrm{B}$ & $\mathrm{B}$ \\
\hline Donetsk & $\mathrm{E}$ & $\mathrm{E}$ & $\mathrm{C}$ & $\mathrm{B}$ & $\mathrm{E}$ \\
\hline Zhytomyr & $\mathrm{D}$ & $\mathrm{D}$ & $\mathrm{D}$ & $\mathrm{D}$ & $\mathrm{D}$ \\
\hline Transcarpathian & $\mathrm{D}$ & $\mathrm{D}$ & $\mathrm{D}$ & $\mathrm{D}$ & $\mathrm{D}$ \\
\hline Zaporozhzhia & $\mathrm{C}$ & $\mathrm{D}$ & $\mathrm{C}$ & $\mathrm{C}$ & $\mathrm{C}$ \\
\hline Ivano-Frankivsk & $\mathrm{D}$ & $\mathrm{D}$ & $\mathrm{D}$ & $\mathrm{D}$ & $\mathrm{D}$ \\
\hline Kiev & $\mathrm{C}$ & $\mathrm{C}$ & $\mathrm{C}$ & $\mathrm{C}$ & $\mathrm{C}$ \\
\hline Kirovograd & $\mathrm{D}$ & $\mathrm{D}$ & $\mathrm{D}$ & $\mathrm{D}$ & $\mathrm{D}$ \\
\hline
\end{tabular}




\begin{tabular}{|l|l|l|l|l|l|}
\hline Luhansk & E & E & E & E & E \\
\hline Lviv & C & C & C & C & C \\
\hline Mykolaiv & D & D & D & D & D \\
\hline Odesa & C & C & C & C & C \\
\hline Poltava & C & D & D & D & D \\
\hline Rivne & D & D & D & D & D \\
\hline Sumy & D & D & D & D & D \\
\hline Ternopil & B & C & B & C & B \\
\hline Kharkiv & D & D & D & D & D \\
\hline Kherson & D & D & D & D & D \\
\hline Khmelnytsky & D & D & D & D & D \\
\hline Cherkasy & D & D & D & D & D \\
\hline Chernivtsi & D & D & D & A & D \\
\hline Chernihiv & A & & A \\
\hline
\end{tabular}

Source: calculated by the authors.

The obtained dynamic indicators of the state of clustering of the regions of Ukraine in terms of economic security in terms of digitalization during 2016-2020 indicate relative stability of the existing cluster structure. The most significant differences are observed in the situation of Zaporizhzhia region (transition to cluster D in 2017), Kharkiv region (transition to cluster C in 2017 and 2019), Poltava region (transition to cluster $\mathrm{D}$ for the period during 2017-2019) and Donetsk region (transition to cluster C in 2018 and transition to cluster B in 2019).

\section{Conclusion}

Thus, calculations and clustering of regional economic systems on the example of the regions of Ukraine in accordance with the level of economic security in terms of digitalization showed that most regions belong to cluster $\mathrm{D}$, which includes regions with medium and low level of industrial development and relevant human development indicators that significantly reduces the level of overall innovation potential of the cluster in the context of intensifying the processes of the economy digitalization.

The scientific novelty of the obtained results lies in the development of methodological support for assessing economic security of regional economic systems in terms of digitalization, which is built using the systematic approach and in contrast to the existing ones, and involves the identification of indicators-criteria for clustering using the Ward's method of the assessment of regional economic systems in the context of digitalization.

Further research requires the development of measures to increase the resilience of the economic security system of regional economic systems in terms of intensifying the use of digitalization.

\section{References:}

[1] Abramova A., Shaposhnykov K., Zhavoronok A., Liutikov P., Skvirskyi I., Lukashev O., Ecosystem of VAT Administration in ECommerce: Case of the Eastern Europe Countries, Estudios de economía aplicada, Vol.39(5), 2021. http://dx.doi.org/10.25115/eea.v39i5.4909.

[2] Agarkov G.A., Tarasyeva T.V., Assessment of passive economic security of the socioeconomic system of the region, AIP Conference Proceedings, Vol. 2293, 2019. https://doi.org/10.1063/5.0030882

[3] Akhmetshin E.M., Pavlyuk A.V., Kokorev A.S., Lazareva T.G., Artemova E.I., Assessment of economic security of the region (on the example of Chelyabinsk region), Journal of Applied Economic Sciences, Vol. 13(8), 2018, pp. 2309-2322.

[4] Burlutskiy S.V., Burlutska S.V., Marhasova V.G., Sakun O.S., The relationship between short-term fluctuations and stages of economic cycle: The case of Ukraine, Espacios, Vol.40(10), 2019, pp. 1-8.

[5] Dobrovolska O., Marhasova V., Momot O., Kozii N., Chyzhyshyn O., Evolution and current state of money circulation in Ukraine and the world, Estudios de Economia Aplicada, Vol.39(5), 2021.

[6] Dubyna M., Zhavoronok A., Kudlaieva N., Lopashchuk I., Transformation of household credit behavior in the conditions of digitalization of the financial services market, Journal of Optimization in Industrial Engineering, Vol.14(1), 2021, pp. 97-102. DOI: $10.22094 / J O I E .2020 .677835$.

[7] Glechikova N., Nechaev V., Seriogin A., Modeling the Development of the Economic Security System of Regions as the Basis of 
Stability. Complex Systems: Innovation and Sustainability in the Digital Age. Studies in Systems, Decision and Control, Vol. 282, 2020, pp. 141-148. https://doi.org/10.1007/978-3030-44703-8_16.

[8] Grigoraş-Ichim C.E., Cosmulese C.G., Savchuk D., Zhavoronok A., Shaping the perception and vision of economic operators from the Romania - Ukraine - Moldova border area on interim financial reporting, Economic Annals-XXI, Vol. 173(9-10), 2018, pp. 60-67. https://doi.org/10.21003/ea.V173-10.

[9] Kholiavko N., Zhavoronok A., Marych M., Viknianska A., Kozlovskyi S., Herasymiuk K., Countries disposition in the global scientific and educational area: management and clustering, International Journal of Management, Vol.11(5), 2020, pp. 400-415. https://doi.org/10.34218/IJM/11.5.2020.039.

[10] Kholod S., Iefimova G., Halynska, Y., Abdullah Alnuaimi H.R.S., Ali Alhammadi T.A.M., Risk management tools for emergencies in the context of global informatization, Estudios de Economia Aplicada, Vol.39(5), 2021.

[11] Kozyrieva O., Khudolei V., Vyhovska V., Zabashtanskyi M., Rogovyi A., Mining Business Risk Management. Vth International Innovative Mining Symposium, Section Mining Regions' Sustainable Development, Vol. 174, 18 June 2020.

[12] Kravchenko V., Kudryavtseva T., Kuporov Y., A method for assessing threats to economic security of a region: A case study of public procurement in Russia, Risks, Vol. 9(1), 2021. https://doi.org/10.3390/risks9010010.

[13] Mayorova T., Zabashtanskyi M., Zhuk O., Petrenko I., Zveruk L., Babich I., Mehanizm of finansial planning optimization in the corporations, International Journal of Management, Vol. 11 Is. 5, 2020, pp. 846-857.

[14] Mejokh Z., Kapustina N., Kakhrimanova D., Safronova A., Yussuf A., Urban Transport and Logistics Infrastructure as an Element of Economic Security in the Region, Advances in Intelligent Systems and Computing, Vol. 1116, 2019, pp. 589-597. https://doi.org/10.1007/9783-030-37919-3_59.

[15] Mints A., Marhasova V., Hlukha H., Kurok R., Kolodizieva T., Analysis of the stability factors of Ukrainian banks during the 2014-2017 systemic crisis using the Kohonen selforganizing neural networks, Banks and Bank Systems, Vol.14(3), 2019, pp. 86-98.
[16] Pesotskiy A.A., Koscheyev V.A., Taranov A.I., Globalization from the Standpoint of Economic Security of a Country and Its Regions: Some Aspects of the Threat Systematization, IOP Conference Series: Earth and Environmental Science, Vol. 666(69). 2020. doi:10.1088/17551315/666/6/062117.

[17] Pestryakov A., Sbrodova N., Titovets A., Digitalization of crop production as a factor in strengthening economic security of the region, E3S Web of Conferences, Vol. 262), 2020.

[18] Pinchuk A., Tkalenko N., Marhasova V., Implementation of circular economy elements in the mining regions, E3S Web of Conferences, Vol.105, 04048, 2019.

[19] Popelo O., Tulchynska S., Garafonova O., Kovalska L., Khanin S., Methodical approach to assessing the innovative development efficiency of regional economic systems in the conditions of the creative economy development, WSEAS TRANSACTIONS on ENVIRONMENT and DEVELOPMENT, Vol. 17, 2021, pp. 685-695. DOI: 10.37394/232015.2021.17.66.

[20] Popelo O., Tulchynska S., Lagodiienko N., Radin A. M., Moskalenko A., Methodical Approach to Forecasting the Intensification of Innovative Development of Regions Using the Mathcad Program, International Journal of Circuits, Systems and Signal Processing, Vol. 15, 2021, pp. 1591-1601. DOI: 10.46300/9106.2021.15.171.

[21] Popelo O., Tulchynska S., Marhasova V., Ivanova N., Samiilenko H., An innovative approach to determine the sustainable development of regions by harmonization of the economic, social and environmental components, Journal of Management Information and Decision Sciences, Vol. 24(S4), 2021, pp. 1-9. DOI: 1532-580624-8-340.

[22] Revko A., Butko M., Popelo O., Methodology for Assessing the Inflence of Cultural Infrastructure on Regional Development in Poland and Ukraine, Comparatie Economic Research. Central and Eastern Europe, Vol. 23(2), 2020, pp. 21-39. https://doi.org/10.18778/1508-2008.23.10.

[23] Rudenko M.N., Development of a sustainable mechanism for economic security of the region, Rivista di Studi sulla Sostenibilita, Vol.2, 2020, pp. 33-47. DOI: 10.3280/RISS2020-002S1004. 
[24] Rudenko M.N., Economic security of the region (Perm krai), Astra Salvensis, Vol. 7(S1), 2019, pp. 385-410.

[25] Shkarlet S., Dubyna M., Shtyrhun K., Verbivska L., Transformation of the Paradigm of the Economic Entities Development in Digital Economy, WSEAS TRANSACTIONS on ENVIRONMENT and DEVELOPMENT, Vol. 16, 2020, pp. 413-422. DOI: 10.37394/232015.2020.16.41.

[26] Shkarlet S., Ivanova N., Popelo O., Dubyna M., Zhuk O., Infrastructural and Regional Development: Theoretical Aspects and Practical Issues, Studies of Applied Economics, Vol. 38(4), 2020. https://doi.org/10.25115/eea.v38i4.4002.

[27] Solosich O., Popelo O., Nusinova O., Derhaliuk M., Tulchynska S., Ensuring economic security of regions as a potentialforming space in the conditions of intellectualization, Academy of Entrepreneurship Journal, Vol. 27(6), 2021, pp. 1-8. DOI: 1528-2686-27-6-617.

[28] Trusova N.V., Hryvkivska O.V., Yavorska T.I., Prystemskyi O.S., Kepko V.N., Prus Y.O., Innovative development and competitiveness of agribusiness subjects by ensuring the economic security system of the regions of Ukraine, Rivista di Studi sulla Sostenibilita, Vol. 2, 2020, pp. 141-156. DOI: 10.3280/RISS2020002-S1011.

[29] Tulchynska S., Popelo O., Garafonova O., Marhasova V., Tkachenko T., The impact of modernization on the competitiveness increase of the enterprise and provision of its economic security. Journal of Legal, Ethical and Regulatory Issues, Vol. 24(S5), 2021, pp. 1-9.

[30] Tulchynska S., Popelo O., Marhasova V., Nusinova O., Zhygalkevych Zh., Monitoring of the Ecological Condition of Regional Economic Systems in the Context of Sustainable Development, Journal of Environmental Management and Tourism, Vol. 12(5), 2021, pp. 1220-1228. https://doi.org/10.14505//jemt.v12.5(53).06.

[31] Tulchynska S., Popelo O., Vovk O., Dergaliuk B., Kreidych I., Tkachenko T., The Resource Supply of Innovation and Investment Strategies of the Microeconomic Systems Modernization in the Conditions of Digitalization, WSEAS TRANSACTIONS on ENVIRONMENT and DEVELOPMENT, Vol. 17, 2021, pp. 819-828. DOI: 10.37394/232015.2021.17.77.

[32] Viknianska A., Kharynovych-Yavorska D., Sahaidak M., Zhavoronok A., Filippov V.,
Methodological approach to economic analysis and control of enterprises under conditions of economic systems transformation, Naukovyi Visnyk Natsionalnoho Hirnychoho Universytetu, Vol. 4, 2021, pp. 150-157. https://doi.org/10.33271/nvngu/2021-4/150.

[33] Viknianska A., Kharynovych-Yavorska D., Sahaidak M., Zhavoronok A., Filippov V., Methodological approach to economic analysis and control of enterprises under conditions of economic systems transformation, Naukovyi Visnyk Natsionalnoho Hirnychoho Universytetu, Vol.4, 2021, pp. 150-157. https://doi.org/10.33271/nvngu/2021-4/150.

[34] Vovk O., Kravchenko M., Popelo O., Tulchynska S., Derhaliuk M., Modeling the Choice of the Innovation and Investment Strategy for the Implementation of Modernization Potential, WSEAS TRANSACTIONS on SYSTEMS and CONTROL, Vol.16, 2021, pp. 430-438. DOI: 10.37394/23203.2021.16.38.

\section{Creative Commons Attribution License 4.0 (Attribution 4.0 International, CC BY 4.0)}

This article is published under the terms of the Creative Commons Attribution License 4.0 https://creativecommons.org/licenses/by/4.0/deed.en _US 